\title{
ENGINEERING CHALLENGES IN KARST
}

\author{
INŽENIRSKI IZZIVI V KRASU
}

\author{
Zoran STEVANOVIĆ ${ }^{1} \&$ Petar MILANOVIĆ ${ }^{2}$
}

\begin{abstract}
Zoran Stevanović \& Petar Milanović: Engineering challenges in Karst

Anisotropy and heterogeneity of karstified rocks make them the most problematic media for various interventions which are needed in engineering practice. The long history of attempts to adapt karstic nature to human needs started with the utilization of karstic aquifers: tapping large springs, transferring their waters to the long distances, improving minimal flows or capturing fresh water in coastal areas. During the $20^{\text {th }}$ century the number of other challenges such as building dam and reservoirs, and constructing roads and railways, bridges, tunnels, new settlements open a new era in engineering works but also in collecting new knowledge and experience for the karstology and hydrogeology sciences. Today, almost no engineering projects can be implemented without a proper environmental impact assessment, which establishes a better balance between human and ecological needs.
\end{abstract}

Key words: karst, aquifer, engineering, environment, impact.

\author{
Izvleček \\ Zoran Stevanović \& Petar Milanović: Inženirski izzivi $v$ \\ Krasu
}

Anizotropija in heterogenost zakraselih kamnin sta lastnosti, ki povzročata, da so te najbolj problematičen medij za različne posege, ki so potrebni v inženirski praksi. Dolga zgodovina poskusov, da bi prilagodili kraško naravo človekovim potrebam se je začela $\mathrm{z}$ izrabo kraških vodonosnikov: izkoriščanje velikih izvirov, prenos vode na dolge razdalje, poviševanje minimalnih pretokov ali zajemanje vode na obalnih območjih. V 20. stoletju je število drugih izzivov, kot so gradnja jezov in rezervoarjev, cest in železnic, mostov, predorov, novih naselij odprla novo obdobje $\mathrm{v}$ inženirstvu. Poleg tega je botrovala zbiranju novih krasoslovnih in hidrogeoloških znanj in izkušenj. Danes skoraj noben inženirski projekt ne more biti izveden brez ustrezne presoje vplivov na okolje, kar vzpostavlja boljše ravnotežje med človekovimi in ekološkimi potrebami.

Ključne besede: kras, vodonosnik, inženiring, okolje, vpliv.

\section{INTRODUCTION}

A karst environment is present on $10-15 \%$ of the continental ice-free surface of our planet (Ford \& Williams 2007) and where there is karst there are regularly many contrasts and challenges for its inhabitants. In many karstic places worldwide, there are limited natural resources: high mountains often function as recharge zones with a shortage of water on their surface. The "fight for water" in such extreme conditions may result in migra- tion of local inhabitants, reduction in the number of cattle and small ruminants, and limited cropping (Stevanović 2015a). In contrast, in drainage zones of littoral karst there is plenty of water, but salt water intrusion often disturbs the fresh water supply.

What makes karst and karstic aquifer systems so specific? The two main characteristics of karstic aquifers are anisotropy and heterogeneity. Anisotropy means

${ }^{1}$ Centre for karst hydrogeology, Department of Hydrogeology, University of Belgrade - Faculty of Mining \& Geology, Belgrade, Serbia

2 IAH National Committee for Serbia, Belgrade

Received/Prejeto: 09.02.2015 
that one physical property varies with direction and this term almost becomes the first association with the word "karst". Heterogeneity as a variation of a property from site to site within the same formation means frequent and great variation in fissuration and cavernosity, so that compact blocks, small fissures, but also large cavities may be jointly present. As a result, with full justification "Expect the unexpected" becomes a phrase used by many hydrogeologists and engineers dealing with karst and its properties (Atkinson 1986; Milanović 2004; Ford \& Williams 2007; Ford 2014).

To make karst and its nature sustainable for human lives is not an easy task and various kinds of intervention are sometimes needed to adapt such an ambience to human needs. These adaptation efforts have a very long history, starting with employing the caves as hu- man shelters and safe havens. Later on, the focus was on springwater use. The tapping structures are an ancient art, as old as the first civilizations: in China, Babylon, Persia, Israel and Egypt there are many ancient remnants of intake structures around large springs. Rounded arches appeared first in Mesopotamian brick architecture but were further developed and systematically applied by Romans enabling the construction of long aqueducts to transport water to long distances. Man continually attempts to adapt nature but these efforts greatly depend on technical development and available tools. During the $20^{\text {th }}$ century and especially in its second half, many successful projects were implemented in different karst regions around the world. However, a number of failures confirm that karst is a risky environment for different aspects of water utilization and control (Milanović 2000).

\section{HISTORICAL OVERVIEW OF RESERVOIR AND EXTRACTION CONSTRUCTIONS IN KARST}

Karstic rocks and aquifer systems in principle provide the largest springs. These springs are commonly used as central places around which to create settlements. For instance, Jerusalem is one such town. Gihon spring issues from Turonian limestones below the city walls but in order to deliver water closer to the citizens and avoid the capture of springwater during a siege, additional engineering works were implemented. Frumkin and Shimron (2006) studied a tunnel more than $500 \mathrm{~m}$ long which delivered water to the Siloam water pool. From radiometric dating (C14 and U-Th), X-ray diffraction methods and microscopic analyses of the sediments taken from tunnel's bottom, speleothems and plaster, they found that the tunnel structure dates back to 700 BC. According to Frumkin and Shimron (2006), the Siloam tunnel is the oldest accurately-dated long tunnel constructed without using intermediate shafts. They also concluded that excavation took place from the two sides and by excavators which depended on acoustic communication. Similarly, a tunnel more than $1000 \mathrm{~m}$ long without intermediate shafts was built in Greece on Samos Island (6BC) but later on in Roman time vertical intermediate shafts became common and regularly applied in such structures.

Excavating a long tunnel to tap groundwater (GW) with a series of vertical shafts is an ancient art widely applied in Mesopotamia and the Persian Kingdom. These structures called qanats (or kharezes) are built to enable gravity transport of the water issuing from karstic rocks covered by or laterally connected to the younger (Tertiary or Quaternary) sediments. This is in fact a kind of tapping of a subsurface flow from a karstic aquifer, and excavation takes place in adjacent semi-consolidated rocks (Fig. 1). As such, several thousand qanats were
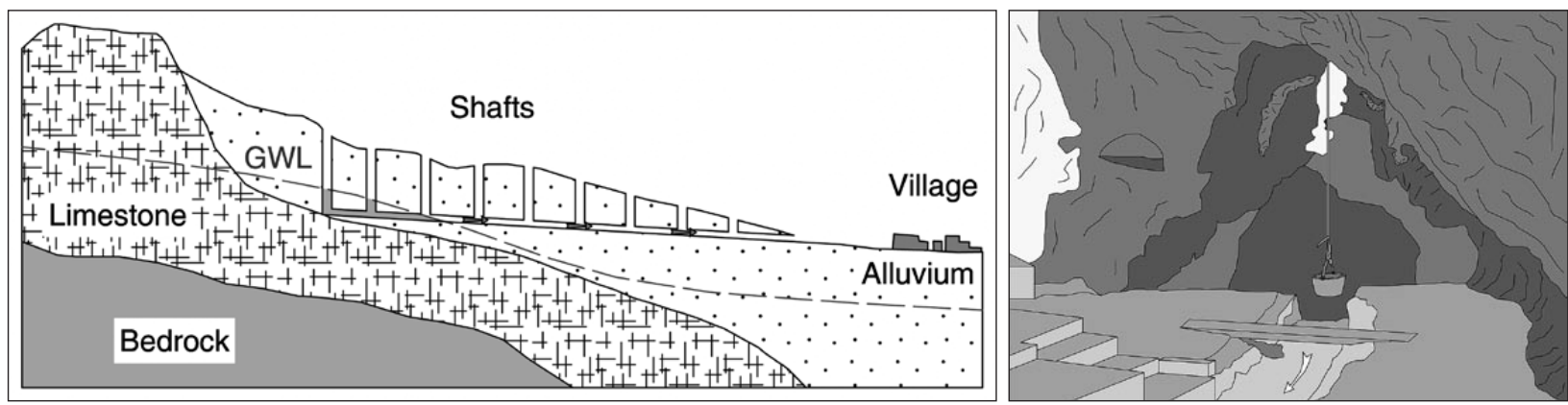

Fig. 1: Schematic cross section and qanat function. Dug channel is extended up to hard limestone rocks and the groundwater table, while water freely flows towards discharge points or can be used by bucket via open shaft. 
built across what today is known as Iran for potable water supply or irrigation purposes.

But, if adjacent relatively softer rocks are missing and the water table is deep below the surface, the problem of tapping groundwater from hard limestone rocks becomes larger. For instance, Persepolis, the capital of the Persian Kingdom, is surrounded by Sarvak Fm. limestones, while the terrace and basin's sediments where the city is settled are of low permeability and do not contain groundwater. To supply the city with water, an extraction well was excavated in very hard rocks. As a final result a very large quadratic shape shaft ("the stone well") was attached to long delivery channels also dug out along the contact of Sarvak karstic aquifer and adjacent younger sediments (Fig. 2).

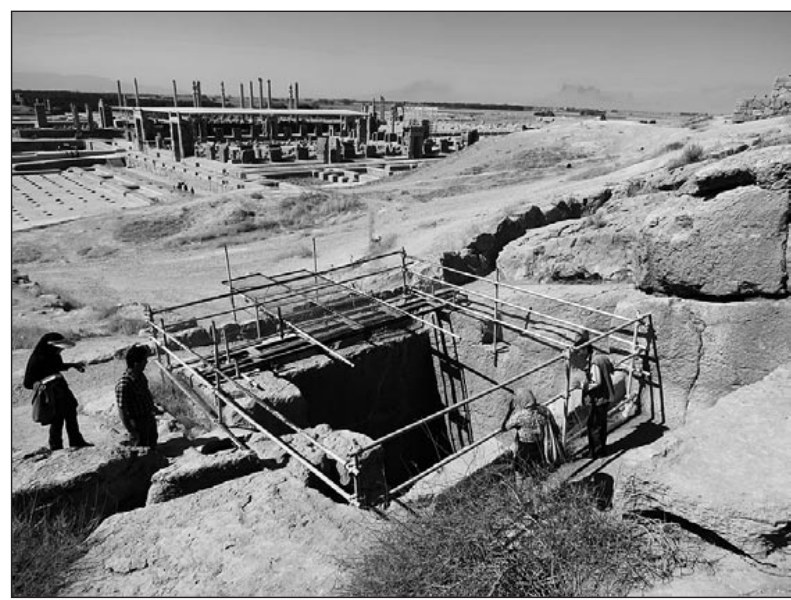

Fig. 2: Stone well at the edge of Sarvak Fm. limestones and near the historical town of Persepolis (Photo: Z. Stevanović).

The attention of skilled labourers was occupied both by digging tunnels and wells which were masterworks in ancient Mesopotamia and Persia, and by bridging the river for water transport. For example, in order to supply the city of Nineveh (today Mosul) with water of better quality than that of the nearby Tigris, the Assyrian emperor Sanherib (Sennacherib), 703-681 BC, son of Sargon II, constructed the intake systems at the Khanis karstic spring (near Atrush, $16 \mathrm{~km}$ farway). The spring water flowed to the city walls via one of the first aqueducts ever built (Fig. 3) (Reade 1978; Stevanović 2010).

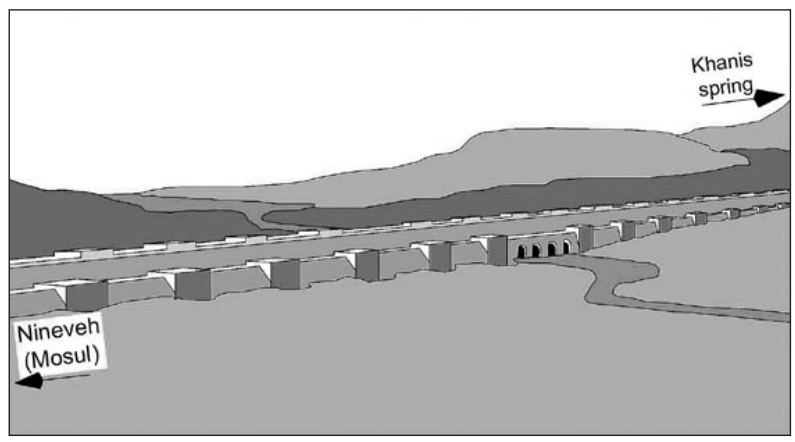

Fig. 3: Scheme of aqueduct crossing one of the streams between Nineveh and Atrush (from Stevanović 2010).

Although the famous Greek philosophers and mathematicians Pythagoras and Archimedes developed principles for the functioning of hydraulic structures, and the Greeks built many impressive structures, it is the Roman times that are a golden age of ancient water engineering. The development and wider application of rounded arches enabled the construction of aqueducts for water transportation and long-distance delivery of springwater (Bono \& Boni 1996). For instance, for the historical city of Rome, 11 long aqueducts delivered more than $13 \mathrm{~m}^{3} / \mathrm{s}$ of springwater from distances ranging from 16 to $91 \mathrm{~km}$ (Lombardi \& Corazza 2008).

Unfortunately, since the collapse of the Roman Empire many masterworks have been completely destroyed and in the Middle Ages the only alternative to the water from the Tiber River was the Aqua Virgo fountain (today Fontana di Trevi, Fig. 4). For this purpose a small fortress

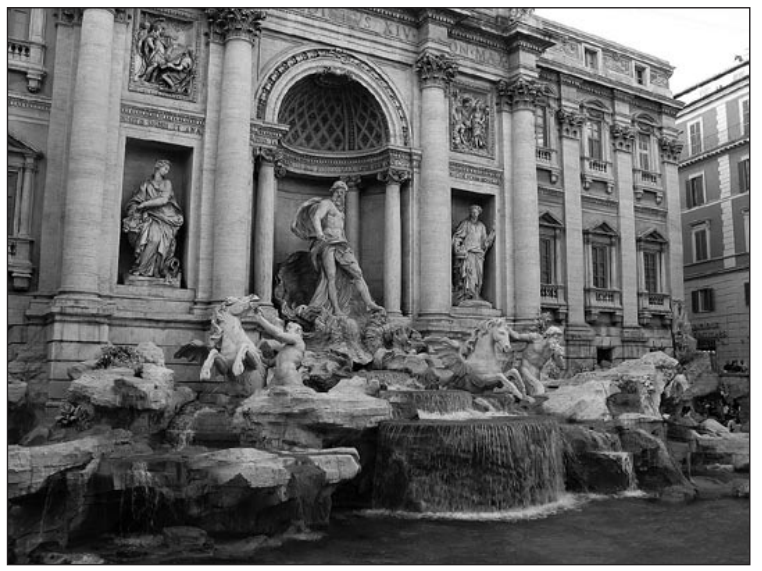

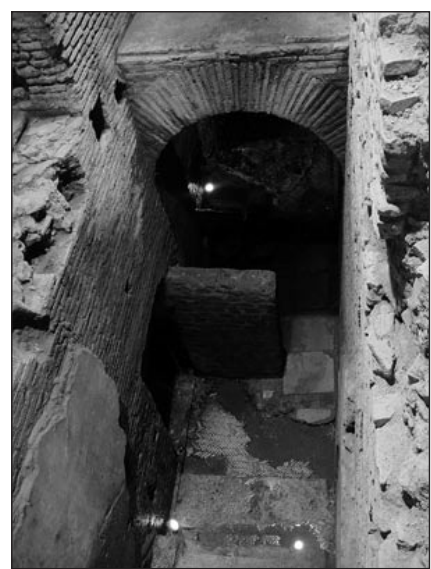

Fig. 4: Fontana di Trevi, the famous fountain in the heart of Rome getting water from the ancient aqueduct Aqua Virgo (left) and remnants of underground water ways in Trevi quarter (Photo: Z. Stevanović). 
was constructed nearby and armed guides controlled its proper functioning.

A typical example of the fact that major cities were created around major springs in karst is found in the Adriatic basin. All four major settlements established by Romans, today on Italian and Croatian shorelines, are linked with springs and depend on springwater supply (Stevanović \& Eftimi 2010): Trieste - Timavo submarine springs, Rijeka - Zvir group of springs in Riječina gorge, Split - Jadro spring and Dubrovnik - Šumet spring.

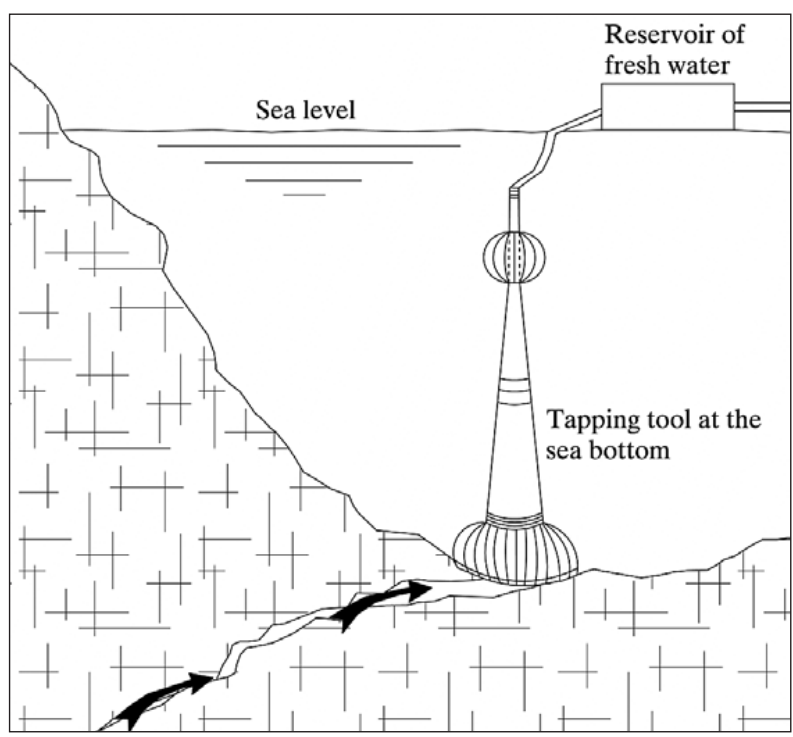

Fig. 5: Simplified scheme of underwater device for capturing fresh water flow and drive it to the surface.

One of the main historical challenges in karst was to tap coastal springs. On the Mediterranean shoreline and islands, but also at many places worldwide (Black Sea, Persian Gulf, Florida, Caribbean basin), submarine or karstic springs discharge at or below sea level. Most of them are brackish and various attempts have been made to tap fresh groundwater before they are mixed with the sea water. The Phoenicians constructed special collective boats with iron funnels and leather pipes to force fresh waters to flow upwards to the surface. Fresh water was also tapped by tubes and bells driven down spring outlets (Fig. 5) or amphorae to catch the flow (Bakalowicz et al. 2003). A similar attempt was made by Nymphea, the French company which tested their device near the Italian-French border (Menton) in summer of 2003. By placing the plastic dome ("Tulip") at the sea bottom 36 $\mathrm{m}$ deep and 800 meters from the coast, discharges of $80-120 \mathrm{l} / \mathrm{s}$ of fresh water were obtained. However, the initial TDS of $1.4 \mathrm{~g} / \mathrm{l}$ increased during the test confirming that total isolation had not been achieved. Moreover, increased salinity of other nearby discharge outlets due to disturbed pressure in the aquifer system resulted in the conclusion that much improvement is needed to secure the proper application of this device (Fleury 2005). Salinity certainly might be reduced if karst conduits and fissures, with the exception of the main outlet, were properly plugged, but this is a very difficult task.

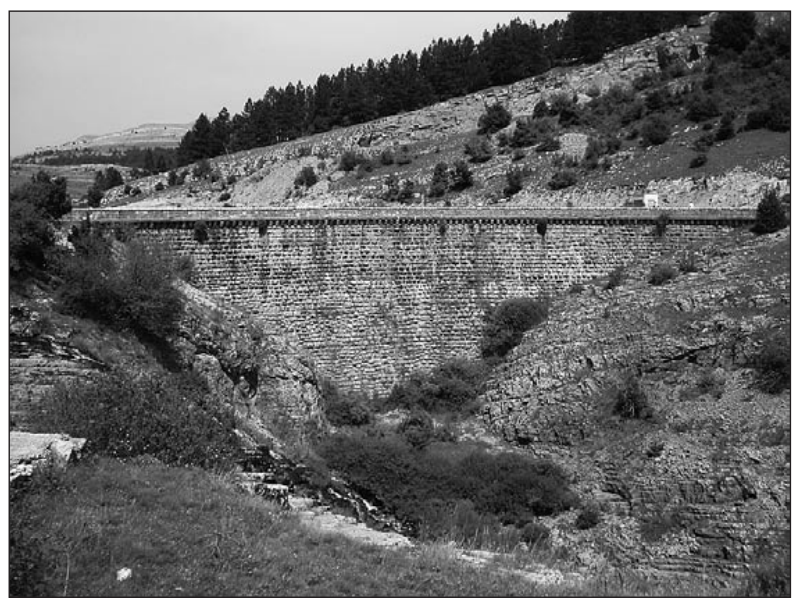

Fig. 6: Klinje dam. Still functioning successfully (Photo: P. Milanović).

Not only were local inhabitants living in karst attracted by water tapping and delivery: tapping springwater is not an engineering job by definition, and many intake structures worldwide were constructed by semiskilled workers, or by labourers experienced just enough to perform such tasks. People living within the karst face many other challenges: to secure cultivated land, construct roads in high mountains with steep slopes, bridge deep canyons for railways, and build towns and houses where the only available materials were lime rocks (Bakalowicz 2005). But in the $18^{\text {th }}$ and $19^{\text {th }}$ centuries, the long and interminable fight for securing water and food in areas with limited natural sources pushed many of their citizens to travel overseas. These migration waves towards the New World especially concerned countries in the Mediterranean basin. It was at the end of the $19^{\text {th }}$ century when the situation and living conditions started slowly to improve, thanks mostly to the global technical progress.

Large seasonal variations in the water regime are typical of karstic regions in the Dinaric system (Bonacci 1987) which is considered locus typicus for karst. Although classical floods are not very common due to the large infiltration capacity of the ponors, they cannot always absorb runoff water from intensive rainfall, which causes regular flooding of many karst poljes. This is also the main reason why large projects to regulate river flows were initiated; the Klinje dam (Mušnica stream, 

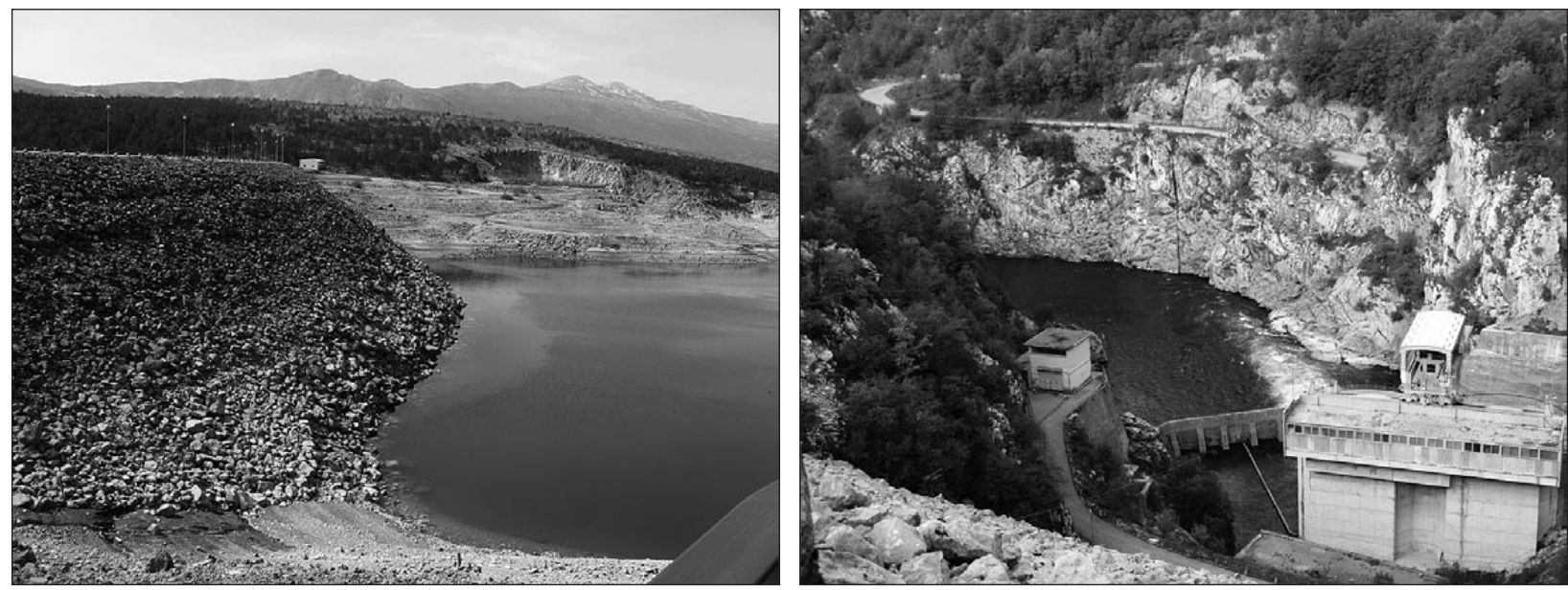

Fig. 7: The two dams in the Dinaric karst of Croatia: Cetina Reservoir and Peruća dam (left), Kruščica Lake and Sklope dam (right). Watertightness of Cetina is satisfactory (losses at the level of $1.5 \%$ of average riverflow), while Kruščica has considerable water leakage $\left(\sim 1 \mathrm{~m}^{3} / \mathrm{s}\right)$ (Photos: Z. Stevanović).

Bosnia and Herzegovina) was the first built in the period 1888-1896 (Milanović 2006, 2014; Fig. 6), while the hydro-electrical power plant (HPP) at Kraljevac (Cetina, Croatia) was erected in 1912. Today many streams are dammed and their waters are utilized by HPPs. The major dams and reservoirs were built on the Cetina, Neretva, Trebišnjica, Zeta, and Drini rivers (Fig. 7).
The revolutionary conclusion that a dam and reservoirs might be successfully built even in such porous media as karst has been further exploited at many places worldwide, but of course not always with success. However, development of man-made reservoirs offered broad insight and understanding of design and construction phenomena specific only to karst rocks and regions around the world (Milanović 2004).

\section{RESEARCH AND CONCEPTUALIZE THE KARST}

Good planning and extensive research may diminish the risk, but can never totally ensure a positive final result whatever works we undertake in karst. To obtain maximal possible positive effects of our intervention it is therefore important to choose optimal investigation methods and to understand and study well the local karstic system. The greatest impacts on engineering structures occur when caverns are present. Their potential for detection and characterization is very difficult despite intensive investigations. Caverns have been discovered hundreds of meters below ground surface by drilling and tunneling; however, the detection of caverns deeper than $20 \mathrm{~m}$ by geophysical methods is still not easy.

Some of methods are applicable in hydrogeological research in every aquifer system but some are very specific and developed exclusively for karst: Only karst provides the opportunity to delve into its inner secrets to enable confirmation or revision of our ideas and engineering solutions.
In the Book Karst Hydrogeology (Milanović 1981) are presented and explained various methods applied in karst hydrogeology. Some of them are common, but innovative techniques such as the use of geo-bombs were applied for the first time in hydrogeology practice. Goldscheider and Drew (2007) and Goldscheider (2015) describe the so-called Karst hydrogeology toolbox and listed the main available research methods: geological, geophysical and speleological methods, hydrologic and hydraulic techniques, the use of natural tracers such as isotopes and hydrochemical parameters, as well as the application of artificial tracer tests. White (1977), and Smart and Hobbs (1986) discuss conceptualization of karst aquifers. Recently, Krešić (2013) and Krešić and Mikszewski (2013) provided a complete guide to the management and restoration of water in karst environment, including explanation of many methods and kinds of conceptualization of site models. Some of the methods are well-known but also some specific methods have 
been recently developed. The list is very long and in almost every new issue of the hydrogeology journals one may find discussion of new investigation techniques or achievements that may improve the existing ones (Bakalowicz 2005).

Once sufficient basic information on karst system behaviour is collected then a conceptual model can be created. When considering karstic aquifers, several properties have to be evaluated (Stevanović 2015b, modified):

- Geometry (catchment and vertical distribution/ thickness taking into consideration all elements: epikarst, vadose zone, saturated zone, karstification base),

- Aquifer properties (porosity, permeability, conductivity, transmissivity, storativity),

- Recharge mechanism (autogenic, allogenic),

- Groundwater flow directions (high and low water seasons)

- Drainage (springs, subsurface drainage, GW extraction)
- Hydrodynamic conditions (confined, unconfined, piezometric pressure, hydraulic head, watertightness, and similar),

- Relationship of ground and surface waters (regime and impacts throughout the year, kind and quality of surface waters),

- Relationship of adjacent aquifers (boundary conditions, type of barrier, impacts under seasonal variations),

- Groundwater quality (hydrochemistry - macro and micro constituents, microbiology, gases, isotopes, physical properties),

- Aquifer vulnerability to pollution (attenuation capacity, contaminant transport, sanitary protection zones of the sources),

- Regime of groundwater (seasonal variation of GW quantity / depth to water table and discharge, and GW quality).

\section{ENGINEERING WORKS AND CHALLENGES}

There are three major groups of problems when dealing with karst aquifers (Stevanović 2015b, modified):

1. Water resources using - Effective utilization of karstic water resources for drinking water supply and other purposes;

2. Dewatering - Mitigation of karst inflow in mining, reduction of karst poljes flooding, urban areas, dams or other construction works;

3. Protecting - Prevention of pollution and remediation of karst water quality.

All three groups consist of a number of different tasks and challenges and they may also act together. For instance, opening a new source for potable water supply requires adequate GW protection measures and establishment of sanitary protection zones. Similarly, if a dewatering process is necessary to enable secure mining, we should assess if extracted groundwater could be utilized for other purposes.

The majority of engineering works in karst are related to water, but of course not all of them are. There are plenty of problems occurring in dry karst or in its unsaturated zone. Parise and Gunn (2007) describe causes and mitigation measures that could be applied for natural and anthropogenic hazards in karst terrains. Collapse of buildings constructed over sinkholes (dolines) filled by unconsolidated sediments is very common in karst environments (Fig. 8).
Therefore, engineering challenges in karst can be very different and Tab. 1 below is an attempt to list the most common challenges.

Common destructive processes in karst engineering which result from various factors are: massive turbulent flows; the fast erosion of unconsolidated deposits in caverns and joints; the great kinetic energy of underground flows; propagation of hydraulic pressure at large distances (piston effect); and the enormous hydraulic pressures created in periods of full aquifer saturation, including water-hammer and air-hammer effects due to rapid fluctuation of the water levels (Milanović 2014).

Some of the practical experiences and dilemmas resulting from engineering applications in karst during the last decades are presented below.

\section{TAPPING KARSTIC GW}

Ford and Williams (2007) stated that surface and subsurface outcrops of potentially soluble karstic rocks occupy around $20 \%$ of the planet's ice-free land, but probably not more than $10-15 \%$ is extensively karstified and provides the opportunity to store and deliver fresh groundwater. Similar percentage or even a few percent more of the global population using karstic groundwater for drinking purposes.

Taking into consideration the rough figure of an average specific consumption of $65 \mathrm{l} /$ day/capita, whether 

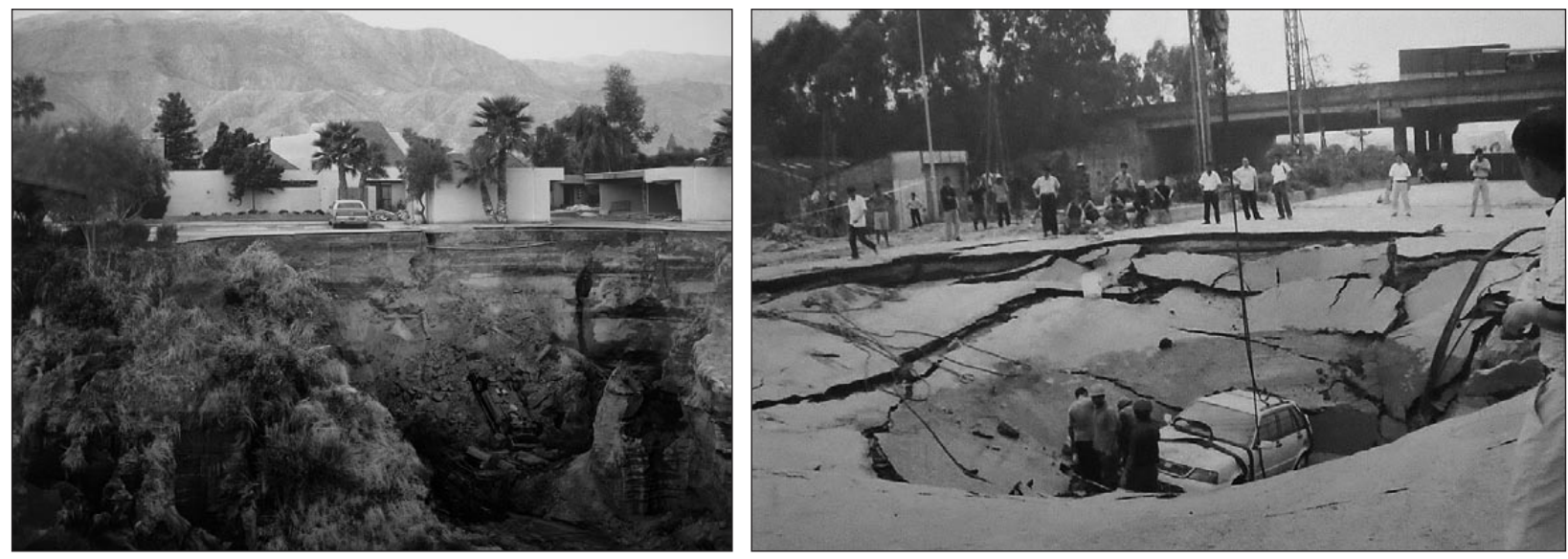

Fig. 8: Sinkhole collapses. From Museum of Modern Art in New York (left) and Geological Museum of the Institute for Karst Research (Guilin, China) (Photo: Z. Stevanović).

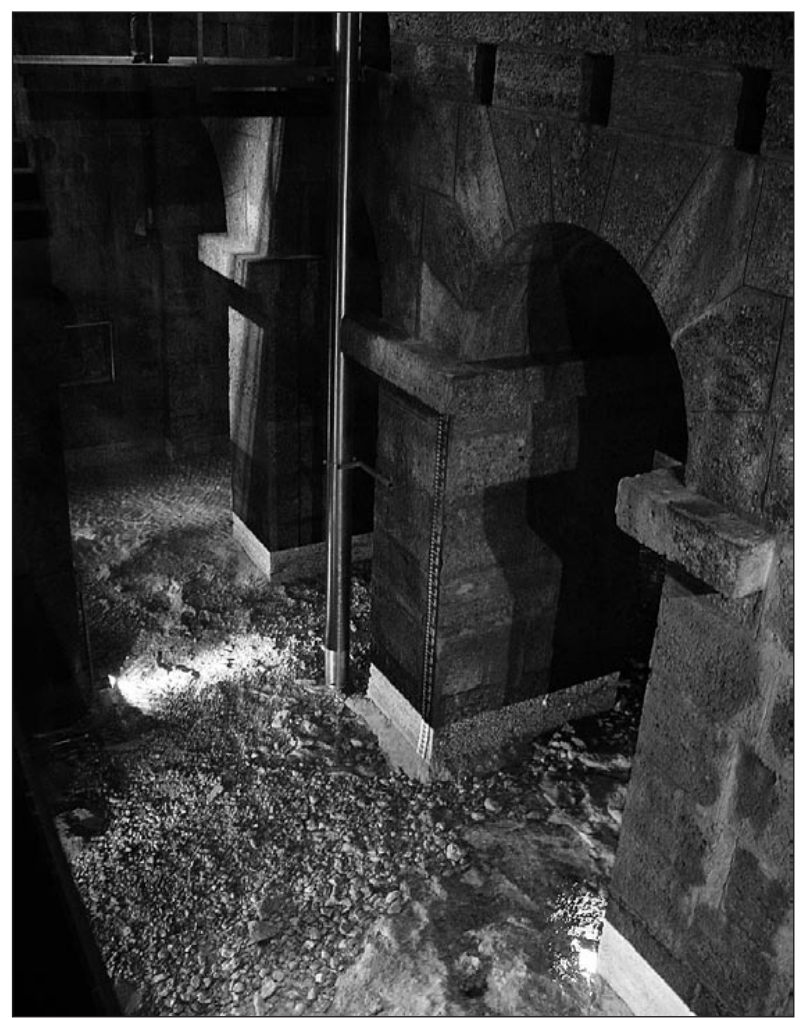

Fig. 9: A karst spring supplying 1.7 million inhabitants. Keiserbrunn spring was tapped for city of Vienna in 1873 as an engineering masterpiece (Photo: Z. Stevanović).

from centralized water utilities (Fig. 9) or individual wells, we could estimate the total use of karstic groundwater on the global scale to be ca. $100 \times 10^{6} \mathrm{~m}^{3} /$ day or an equivalent flow of ca $1100 \mathrm{~m}^{3} / \mathrm{s}$. Compared with available data on total global groundwater withdrawal (Margat \& van der Gun 2013; database of IGRAC, AQUASAT, EUROSTAT) karst aquifers deliver around $1 / 3$ of all the used groundwater.
At many places worldwide karstic springs are utilized simply because there are no other alternatives, but at many others, awareness of their importance and the good water quality are principal factors for such a decision (Stevanović 2015a). However, no statistics exist yet as to how much of this water is provided directly from the springs and how much comes from the wells or other structures. In the developing world it is very difficult, sometimes even impossible, to meet increased demands and provide sufficient water to the population. In fact, population growth is the main reason why many previously used springs are now abandoned. Orientation towards more abundant water resources such as alluvial aquifers, river water or water from newly-constructed reservoirs is a common trend. But in regions where there are no such alternatives, karst aquifers will remain under constant pressure. This is also why many indications of over extraction and even complete depletion of groundwater reserves are evidenced in countries with an arid climate.

To become self-sufficient in wheat after the oil export embargo in 1973, the Saudis developed a subsidized irrigated agriculture based heavily on pumping water from fossil aquifers (Brown 2013). Today, even after the introduction of many remedial measures including desalinization of sea water for aquifer recharge, aquifers are still almost dry. Yemen is pumping around $2 \mathrm{~km}^{3} /$ year of groundwater, of which around $90 \%$ is used in irrigation. Significant water table depletion is present and water distribution by tankers is widely applied (Burke \& Moench 2000). In northern Iraq forced groundwater utilization for irrigation purposes as well as for the water supply of fast-growing urban areas has caused regional drawdown of many aquifers (Stevanović \& Iurkiewicz 2009). The largest Syrian spring and one of the largest in the Mediterranean karst, Ras el Ain no longer exists, having dried 
Tab. 1: List of major tasks and engineering works in karst.

\begin{tabular}{|c|c|c|}
\hline Task / Challenges & Engineering works - Solutions & Impact \\
\hline $\begin{array}{l}\text { Water supplying / } \\
\text { exploiting and providing } \\
\text { potable water, or technical } \\
\text { water to irrigation and } \\
\text { small industry }\end{array}$ & $\begin{array}{l}\text { Tapping springs, drilling wells or constructing other } \\
\text { kind of intakes (shafts, galleries). }\end{array}$ & $\begin{array}{l}\text { Only positive, if water extraction rate is } \\
\text { fixed and controlled. }\end{array}$ \\
\hline $\begin{array}{l}\text { Regulating flow and } \\
\text { natural discharge for water } \\
\text { supply or generating hydro } \\
\text { power }\end{array}$ & $\begin{array}{l}\text { Temporary over-pumping of ascending springs or } \\
\text { drilled wells (during critical periods), building of } \\
\text { subsurface dams, making various interventions in } \\
\text { the catchment (small dams, plunging ponors, re- } \\
\text { transferring streams, etc.). }\end{array}$ & $\begin{array}{l}\text { Could be negative, if pumping rate is } \\
\text { unlimited and uncontrolled (monitoring is } \\
\text { an obligation), but in principle is positive } \\
\text { because of mitigating droughts and } \\
\text { ensuring humanitarian water provision for } \\
\text { various consumers and water dependent } \\
\text { eco-systems; preventing migration of } \\
\text { villagers and livestock; improving sanitary } \\
\text { conditions. In the case of hydropower, } \\
\text { generation providing an economic value. }\end{array}$ \\
\hline $\begin{array}{l}\text { Ensuring watertightness of } \\
\text { dams and reservoirs }\end{array}$ & $\begin{array}{l}\text { Choosing appropriate: dam site, dam type, } \\
\text { height and crest, design and materials, intake } \\
\text { and evacuation structures; preventing leakage } \\
\text { by grouting curtain (certain depth, distance, and } \\
\text { grout mass), plunging ponors or place non-return } \\
\text { valves; regulating reservoir bottom and beds } \\
\text { by geomembranes, impervious clayey blankets, } \\
\text { shotcrete; permanent monitoring of secondary } \\
\text { effects (induced seismicity, piston effects, and } \\
\text { similar). }\end{array}$ & $\begin{array}{l}\text { Positive in case of multipurpose dams: } \\
\text { controlling river flow, preventing floods, } \\
\text { ensuring stable water supply and ecological } \\
\text { flow, generating hydropower energy. } \\
\text { Negative from various ecological aspects } \\
\text { but most of them can be mitigated by } \\
\text { appropriate measures. }\end{array}$ \\
\hline $\begin{array}{l}\text { Securing mining } \\
\text { operations }\end{array}$ & $\begin{array}{l}\text { Excavating only secure and surveyed zones to } \\
\text { prevent incidental inrushes; establishing adequate } \\
\text { defence dewatering system; avoiding works in } \\
\text { saturated zones (if possible) or deplete water } \\
\text { table before mining; keep away from unstable } \\
\text { slopes (due to landslides), unconsolidated rocks; } \\
\text { preventing mixture of waste mine and origin } \\
\text { groundwater; choosing appropriate place for waste } \\
\text { rock dump (make impervious bottom and use foils); } \\
\text { prevent leakage from tailings. }\end{array}$ & $\begin{array}{l}\text { Positive from economical point of view, } \\
\text { but risky and generally negative from } \\
\text { environmental point of view. Precaution } \\
\text { measures are necessary, as well as } \\
\text { monitoring effects of mining operations } \\
\text { and their impact on environment and } \\
\text { endangered species. }\end{array}$ \\
\hline $\begin{array}{l}\text { Building in existing or } \\
\text { creating a new settlement; } \\
\text { constructing the roads and } \\
\text { railways; tunnelling and } \\
\text { bridging }\end{array}$ & $\begin{array}{l}\text { Fully respecting surveying and construction } \\
\text { standards; preparing appropriate designs adapted } \\
\text { to the local circumstances; avoiding flooding areas, } \\
\text { steep slopes, unstable terrains (potential landslides } \\
\text { or rockfall sites); keeping away from registered } \\
\text { open or hidden sinkholes and other depressions } \\
\text { filled with secondary sediments; avoiding shallow } \\
\text { water table presence and carrying on systematic } \\
\text { dewatering and drainage before construction; } \\
\text { lining and tracing tunnels to avoid cavities, highly } \\
\text { fracturated and saturated zones. }\end{array}$ & $\begin{array}{l}\text { Positive, in case that appropriate research } \\
\text { programs are implemented and standard } \\
\text { procedure in civil engineering works } \\
\text { respected; Negative if uncontrolled } \\
\text { housing is taking place, or not respecting } \\
\text { hydrogeological conditions. Permanent } \\
\text { monitoring during construction works. }\end{array}$ \\
\hline $\begin{array}{l}\text { Extracting heat / } \\
\text { geothermal energy } \\
\text { applications; exploiting } \\
\text { mineral and thermo- } \\
\text { mineral waters }\end{array}$ & $\begin{array}{l}\text { Deep drilling should be based on proper and } \\
\text { detailed survey; aquifer testing, chemical analyses } \\
\text { and other complex investigation; feasibility study } \\
\text { (cost-benefit analysis) should precede final design } \\
\text { and implementation; heat pumps application } \\
\text { recommended. }\end{array}$ & $\begin{array}{l}\text { Positive, considering "green" energy } \\
\text { utilization. Also positive if medical and } \\
\text { recreational utilization of thermal water } \\
\text { took place. Negative if utilized water is } \\
\text { not re-injected and does not freely flow to } \\
\text { recipients (doublet system required). }\end{array}$ \\
\hline $\begin{array}{l}\text { Protecting aquifers from } \\
\text { pollution; } \\
\text { remedying polluted } \\
\text { aquifers }\end{array}$ & $\begin{array}{l}\text { Preventive measures are always better than } \\
\text { remedial works, proper aquifer vulnerability } \\
\text { assessment recommended. In case of contaminated } \\
\text { groundwater and rocks various treatment methods, } \\
\text { reactive barriers. }\end{array}$ & $\begin{array}{l}\text { Positive, if preventive measures applied and } \\
\text { sanitary protection zones established. Also } \\
\text { positive in case of properly and carefully } \\
\text { conducted in situ biological or chemical } \\
\text { treatment of rocks and water. Precaution } \\
\text { measures and monitoring in case of work } \\
\text { with dangerous substances. }\end{array}$ \\
\hline
\end{tabular}


out due to forced pumping for irrigation of cotton fields on the Turkish side of the border. In Iran, a country with 77 million people, grain production dropped $10 \%$ between 2007 and 2012 as irrigation wells started to go dry. One-quarter of its current grain harvest is based on overpumping (Brown 2013).

\section{REGULATING DISCHARGE OF KARST GW}

Karst aquifers are a problematic resource due to great variation of the discharge of the karstic springs. During recession periods the local population may suffer from water shortage and it is often a problem to ensure sufficient water for various consumers (Paloc \& Mijatović 1984). During periods of minimal flow followed by increased demand, periods which could continue for months especially in arid parts of the world, water deficit for the population and for dependent eco systems is the rule rather than the exception (Stevanović 2011). It is thus the main challenge for many waterworks to ensure water supply and to avoid restrictions or total interruptions in water provision during these critical periods.

If an aquifer is well karstified and has adequate storage in its deeper parts it is often possible to regulate and manage minimal flow by various engineering interventions. The two main groups of engineering regulation for controlling karstic groundwater can be distinguished:

1. Regulation of discharge zone,

2. Regulations i.e. interventions in wider catchment area.

The categorization of engineering interventions regulating the groundwater flow is as follows (Stevanović 2015c):

1. Spring over-pumping,

2. Drilling wells or other supplementary intakes,

3. Constructing subsurface (underground) reservoirs,

4. Artificial recharge.

Spring over-pumping considers temporary water use ("loan") from deeper aquifer parts. In the case of deep vauclusian springs or even potholes without outflow but in zones with active groundwater flow, it is possible to install pumps into siphon channels and pump the required amount of water supposed to require compensation during further periods of flood. Such a solution is implemented at many places in the karst.

Drilling wells or other supplementary intakes provides more opportunities for "loan" due to much deeper water table depletion. It is in this way that one of the most famous and largest sources - Lez for the city of Montpellier (Avias 1984; Fig. 10) is functioning.

The subsurface (underground) reservoir is based on the retention effect (Milanović 2004): increasing the wa- ter level at the discharge point results in an increase in the hydraulic head inside the aquifer. Such an increase is possible if the discharge point is fully or mostly blocked and artificially controlled (e.g. dam inside channel or in front of the spring or plugging main orifice). According to Yuan (1990) in the Guizhou Province have 16 underground dams been completed in karstified rocks. One of the largest underground reservoirs was formed by the construction of a $15 \mathrm{~m}$ high dam on the Linlangdong underground river.

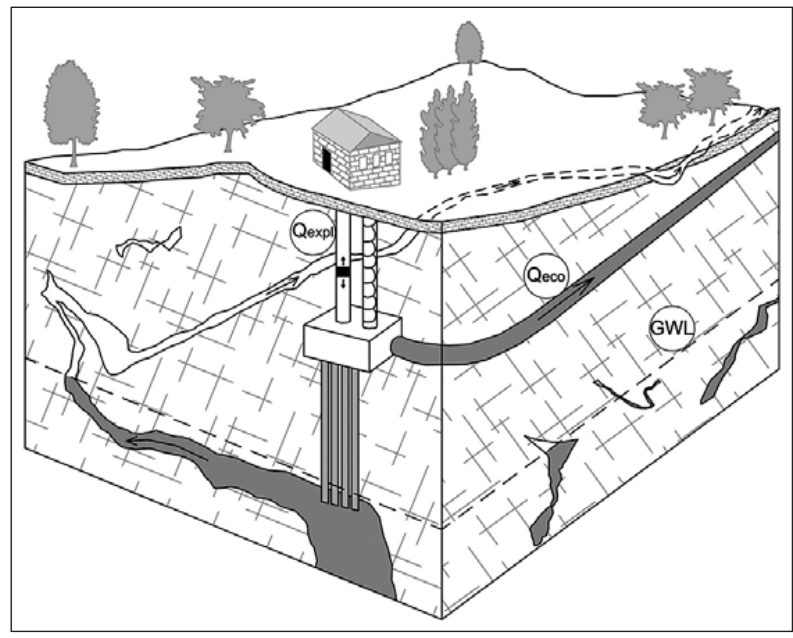

Fig. 10: Lez source and intake scheme (from Montpellier waterworks leaflet, modified by Stevanović, 2015c).

Wulichong underground dam is one of the largest underground structures in China. Kang and Zhang (2002) report that the dam is constructed at the confluence of two underground rivers inside the extremely karstified Triassic limestone. The underground dam consists of a grout curtain $1333 \mathrm{~m}$ long, with maximal depth of $260 \mathrm{~m}$. To block the cavern with underground flow a concrete plug was constructed. The plug is $33.46 \mathrm{~m}$ high, $13.9 \mathrm{~m}$ wide, and $2-10 \mathrm{~m}$ thick. Due to the successful implementation of anti-seepage works this project operates at full capacity.

There are many advantages of underground reservoirs over surface ones. A few are as follows (Stevanović 2010):

- No problems with flooding of infrastructure, fertile land, monuments, or compensation to reallocated people;

- No threat of dam collapse and major destruction downstream;

- No immense evaporation rate from surface and thermal water stratification inside reservoir;

- No negative impact on water quality as in open reservoirs (eutrophication). 


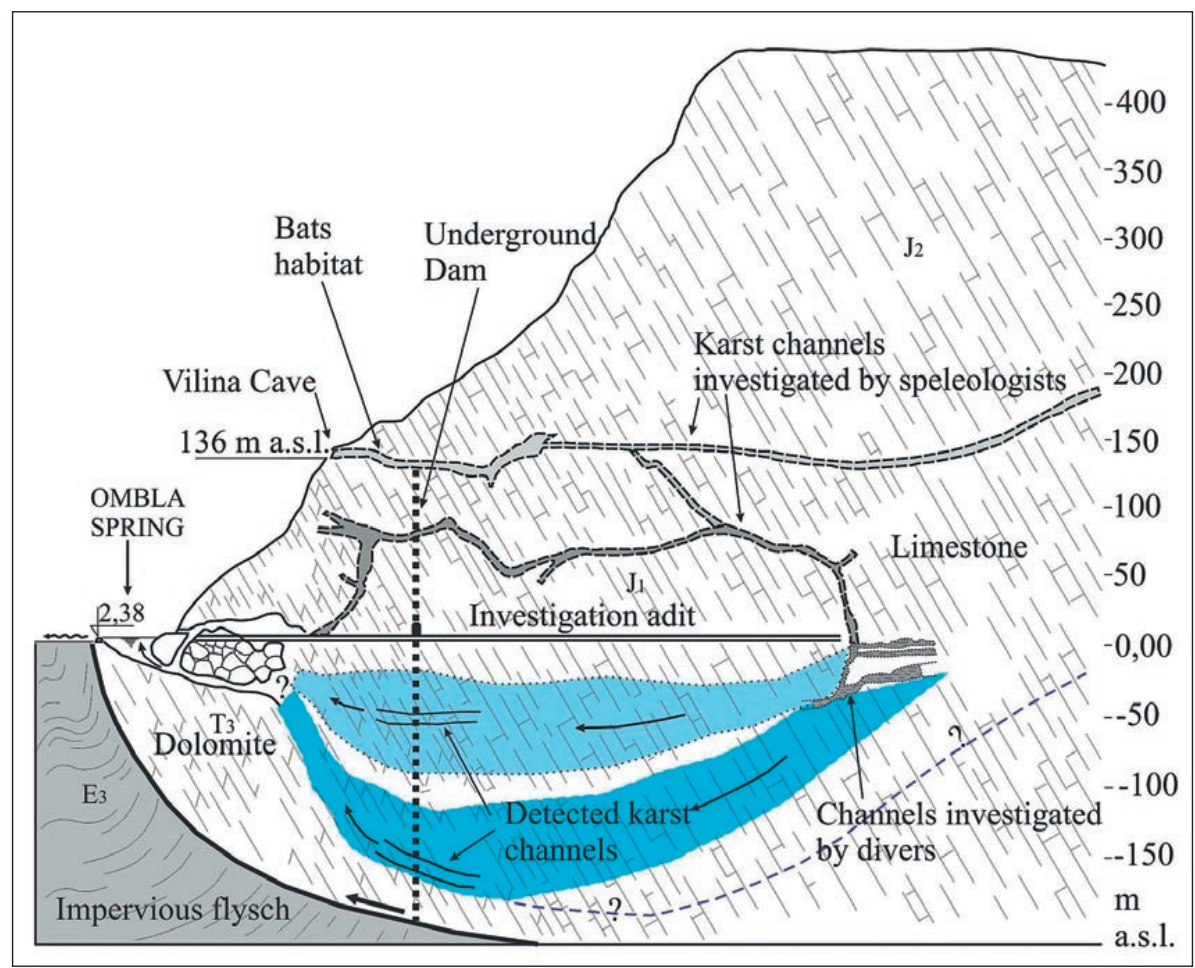

Fig 11: Cross section of the proposed Ombla underground dam and reservoir (after Milanović 2000).

In addition, the underground reservoirs may generate hydropower energy. Well-known and among the largest is the proposed project of the Ombla underground dam and reservoir (Milanović 2004, 2006). Location of the underground dam site is about $200 \mathrm{~m}$ behind the large Ombla spring near Dubrovnik (Croatia) (Fig. 11). The average discharge of the spring is $24.4 \mathrm{~m}^{3} / \mathrm{s}$. The crest of the underground dam is foreseen to be at an elevation of 100-130 m. The estimated underground operational storage space is about 5 million $\mathrm{m}^{3}$ (Milanović 2004, 2014).

Artificial recharge is not as common in karst as in intergranular aquifers: karst aquifers have limited attenuation capacity and only clean water should be used for direct infiltration which may significantly increase operational costs.

\section{DAMMING IN KARST}

Constructing dams and reservoirs in karst is a sensitive task and the risk cannot be eliminated completely even if the best engineering practices are followed (Milanović 2015). Because of the characteristics of karst, it is not easy to select a dam site and reservoir space. A reservoir in karst may fail to fill (Fig. 12) despite extensive investigations and remedial works.

Building of dams expanded worldwide after WW II. Milanović (2015) evaluated conditions for more than 100 dams built in karst that have some problems with seepage from the reservoir. He found the following:

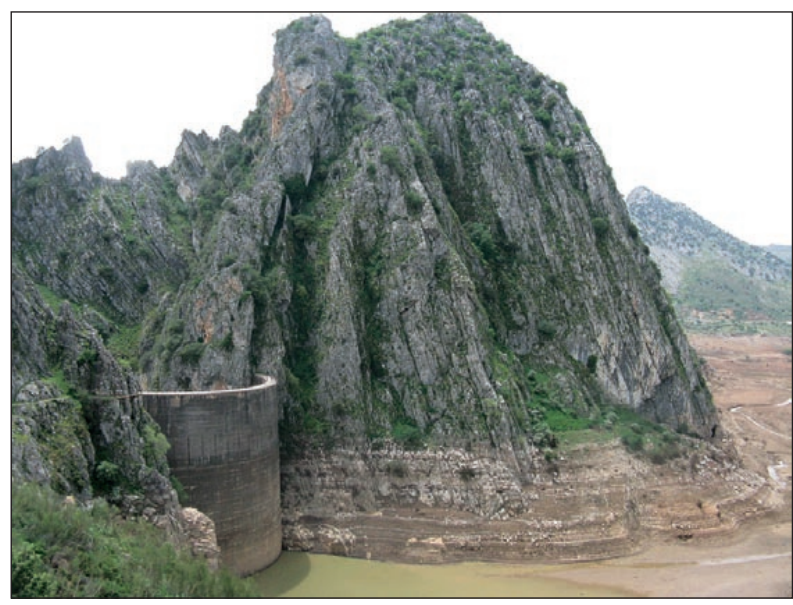

Fig. 12: Empty reservoir of Montejaque dam on Gaduares River in karst of southern Spain. Due to high leakage the reservoir was abandoned in the 1950s (Photo: Z. Stevanović).

- Abandoned constructed dams and reservoirs: 10

- Very high leakage $\left(2->50 \mathrm{~m}^{3} / \mathrm{s}\right): 30$

- Large and very problematic leakage: 13

- Dams and reservoirs in soluble rocks (evaporites): 38

- Large caverns below foundation: 9

- Hypogene karstification and features at dam site: 7

- Unsuccessful or partially successful anti-seepage works: 11 


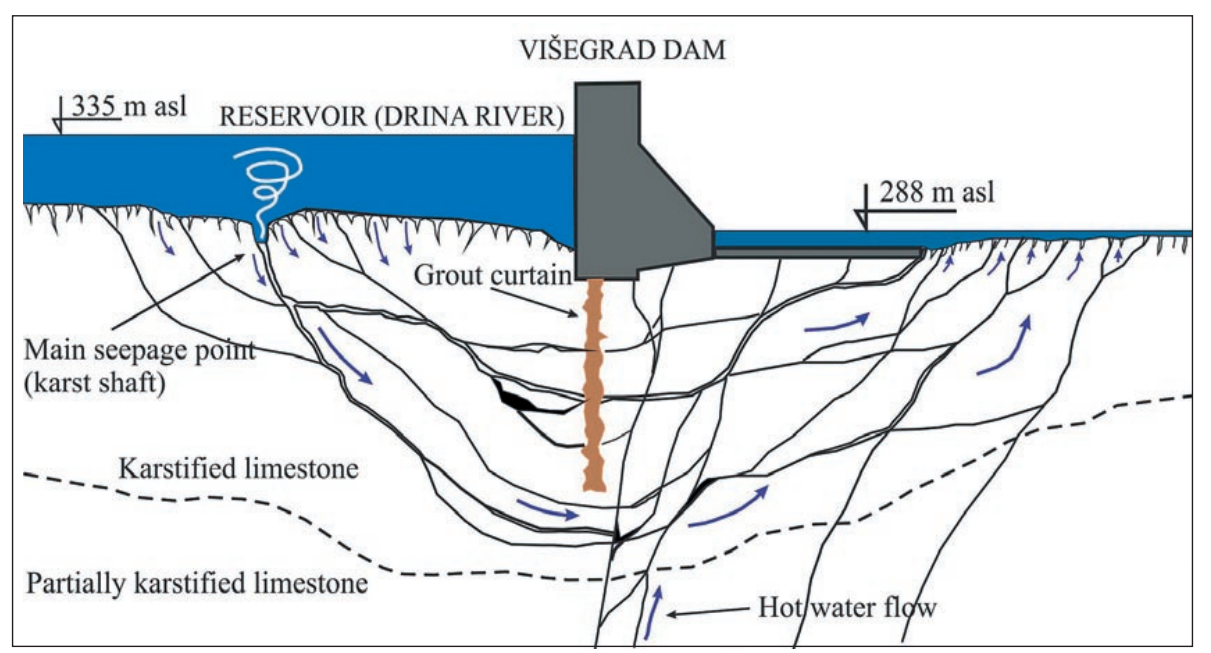

Fig. 13: Cross-section of Višegrad Dam and defined groundwater pathways below the foundation (after Milanović \& Vasić 2014).

- Frozen projects: 13

- Successful anti-seepage works: 29

- Moderate and acceptable leakage: 27

- Re-designed project: 9

Some karstic areas are more problematic due to the presence of highly karstified or soluble rocks. For instance, Yuan stated (1991) that in Guangxi Province alone in China, 644 reservoirs in karst suffer due to leakage.

One of the most complicated and large-scale problems is related to the Mosul Dam in Iraq (110 m high embankment dam, $3600 \mathrm{~m}$ long) where massive dissolution intensity of evaporitic rocks of the Fars Fm. ranging from 42 to 80 tons/day has been recorded. Replacing the volume of dissolved evaporites by grout mix has continued for more than 20 years but without success (new cavities are opening).

Milanović and Vasić (2014) describe the case of significant increase of leaking due to reactivation of fossil caverns in hypogene karst in the foundation of the Višegrad Dam (Drina River, Bosnia and Herzegovina). The leakage below the dam increased from $1.4 \mathrm{~m}^{3} / \mathrm{s}$ (in the year 1990) to $14.68 \mathrm{~m}^{3} / \mathrm{s}$ (in the year 2009). Conducted complex and detailed surveys included remote sensing, geodetic survey, petrology, structural geology, bathymetry and aqua-speleology, geophysics (self-potential, mise a la masse, cross-hole tomography), numerous tracing tests, drilling, pressure tests, "video-endoscopy" (camera logging), and modelling (Fig. 13).

The results of complex survey and 3D positioning of karst conduits enable development of the technical solution for the permanent rehabilitation of seepage by plugging and grouting main cavities and channels. These sealing rehabilitation works have been followed by permanent monitoring (Milanović \& Vasić 2014).

Successful remediation thus requires serious and comprehensive investigations including long period monitoring of groundwater regimes and (in many cases) remedial works during the lifetime of the structure. During construction, modifications and adaptations of structures are very common. The most common remedial works applied to prevent or to mitigate water leakage from reservoirs built in karstic terrains are grouting curtain, impervious blanket, cutoff wall, shotcrete and similar (Fig. 14).

Most of these interventions aim to seal or plug underground conduits, but their success depends on the following (Milanović 2000):

- position of karst channel or concentrated zone flow;

- channel dimensions (cross-sectional area);

- underground flow, characteristics in the channel (permanent or intermittent flow under pressure or with free surface, direction and velocity);

- possible presence of clay and silty cave deposit and their thickness.

The Grančarevo Dam and Bileća Reservoir, as part of the Trebišnjica Multipurpose Hydrosystem, are excellent examples of successful large structure construction in the highly karstified Dinaric karst of eastern Herzegovina (Milanović 2014b). The Trebišnjica Hydrosystem project was initiated in the early 1950s to control the riverflow of Trebišnjica sinking river (the largest in Europe) and prevent flooding of arable land in karst poljes (150 to 250 days annually). Stepwise disposition of karst poljes in Eastern Herzegovina allows optimal multipurpose use of great water potential from elevations of $1000 \mathrm{~m}$ to sea level (Fig. 15). The created and already operational system (phase I) is satisfying demands in water supply, hydropower generation, irrigation - food production, fish farming, recreation, and has a number of secondary benefits, including decreasing the strong emigration trend from the region. 
The Trebišnjica Hydrosystem consists of seven dams, six reservoirs, six tunnels (with a total length of $74 \mathrm{~km}$ ) and four canals (with a total length of $74 \mathrm{~km}$ ). The Phase II (so-called "Upper Horizons") is under construction, and once completed the system will enable irrigation of about $240 \mathrm{~km}^{2}$ of arable land and average annual hydropower output of 856 GWh. The Bileća Reservoir, completely situated in karstified carbonates (volume $1.3 \times 10^{9} \mathrm{~m}^{3}$ ) and without leakage, is one of largest and most successful reservoirs in karst. Important lessons learned during investigation, design, construction and operation have greatly contributed to the development and promotion of scientific karstology and also engineering karstology (Milanović 2014b).

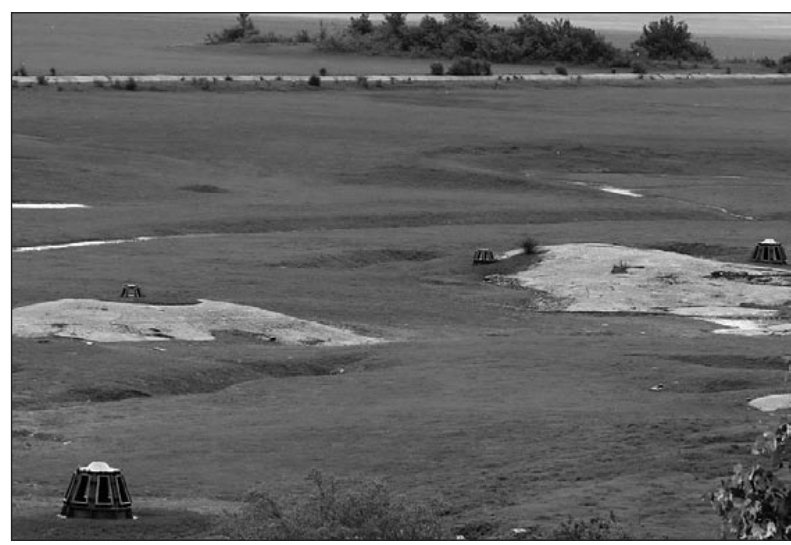

Fig. 14: Impervious concrete blanket and non-return valves at the bottom of Vrtac reservoir in Nikšic polje. Although many protective measures were applied this compensation reservoir is empty most of the time due to highly karstified rocks (Photo: $Z$. Stevanović).

\section{BUILDING AND TRANSPORTATION CONSTRUCTION IN KARST}

As in the case of dams and reservoirs, housing, tunnelling, constructing roads and railways in karst are always delicate tasks. Some failures had catastrophic consequences and even resulted in the loss of human lives.

The peculiarities of the karst environment make it highly vulnerable to a number of geohazards such as sinkholes, slope movements, and floods (De Waele et al. 2011). To these, anthropogenic hazards have to be added, such as pollution events, land use changes resulting in the loss of karst landscape, and destruction of karst landforms (Parise 2015).

Many decreases which happened all over Russia brought about the development of specific methodologies for karst risk assessment and special construction standards for works in designated problematic areas (Tolmachev 2005). For these purposes even the special Antikarst and Shore Protection Institute were established in the city of Dzerzhinsk. Among the most hazardous regions in Russia are Nizhny Novgorod, Tula, Perm, as well as the Republics of Bashkortostan and Tatarstan. About $30 \%$ of the cities and towns in Russia experience a considerable negative influence of karst processes. Industrial facilities and residential buildings in Moscow, Nizhny Novgorod, Dzerzhinsk, Kazan, Ufa, Tula, Bereznyaky and some other cities, towns and settlements have been damaged or destroyed by karst (Tolmachev 2013).

Tolmachev (2005) introduced the term "allowable risk" which depends on a number of factors, including general economic and social national priorities and strategy, but in principle three degrees of economic damage can be distinguished: a) extreme; b) significant and c) insignificant. He also suggested criteria for classification of technogenic effects:

I. According to the nature of the impact (transfer of static and dynamic loads, change of hydrogeological situation),

II. According to the type of area involved (within the territory of a city, town, residential area or a separate building/construction),

III. According to the period of exposure (continuous, prolonged or eventual).

A tunnel in karst appears to be the most vulnerable structure, whether it is a traffic tunnel, headrace tunnel (high-pressure tunnel), water transmission tunnel or dewatering tunnel.

Caverns and channels, empty or saturated with water, are often a key source of different, sometimes catastrophic, problems in tunnelling. The large inflow of underground water considerably retards the excavation of a number of tunnels in karstified rocks. If dewatering by gravity is not possible, huge capacity pumps are a necessary part of the final design.

Defects during the tunnel operation are very common in karst. In particular, the headrace tunnel are extremely sensitive during operation. Frequent and uneven inside and outside strong pressure provokes serious lining demolition.

Marinos (2005) widely discusses problems of tunnelling in karst. He stated that although limestone and most carbonate rocks exhibit good geotechnical behaviour for tunnelling, when they are fully karstified they may induce hazards during tunnelling operations. Work in fully saturated zones may evolve into huge problems: water can affect roof and face stability and in appreciable quantity may impede construction. If the host ground is soft and prone to erosion the risk is further increased.

During excavation of the headrace tunnel for the Dubrovnik Power Plant (16.5 km long and $6 \mathrm{~m}$ diameter), excavation was stopped 25 times due to flooding as a consequence of heavy rains. Although the water table 

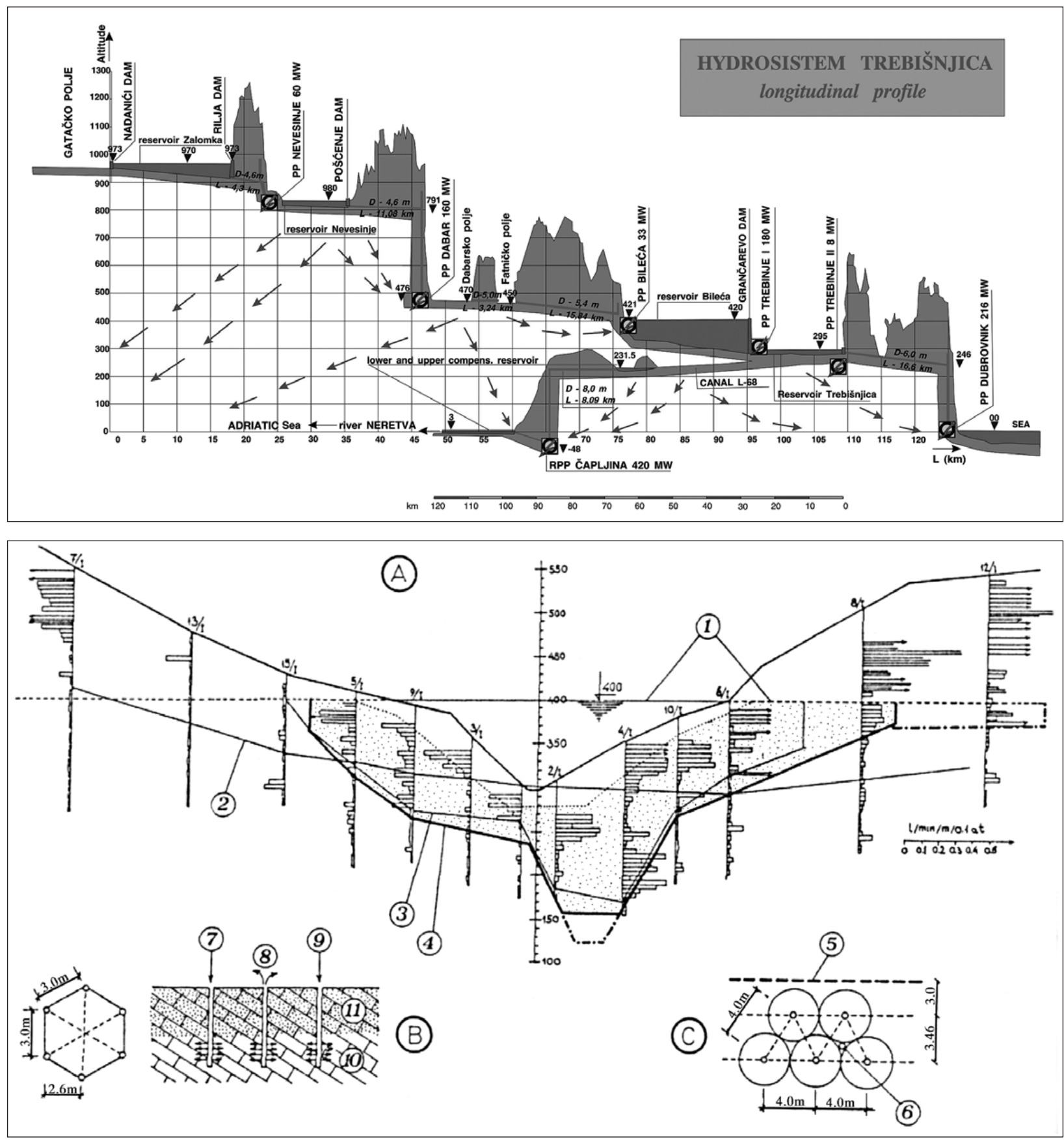

Fig. 15: The Trebišnjica hydrosystem and cascade system of reservoirs (upper) and cross-section along Grančarevo Dam and grout curtain (after Stojić, from Milanović, 2004). Legend: A. Cross-section with permeability test results, B. Scheme of grouting procedure, C. Distribution of grouting boreholes. 1. reservoir elevation, 2. water table during dry period, 3., 4. limits of grout curtains, 5. upstream perimeter of the dam's foundation, 6. control borehole, 7.-11. boreholes and consolidated and unconsolidated portions of rock.

was deep below the tunnel level the water inflow was more than $2.5 \mathrm{~m}^{3} / \mathrm{s}$. Tunnel driving was suspended 160 working days. During excavation of the upstream section of the conveyance tunnel from Fatničko Polje to the Bileća Reservoir, the Herzegovina tunnel (length $15.6 \mathrm{~km}$, diameter $7.1 \mathrm{~m}$ ) was flooded 120 days every year (Fig. 16).
Milanović (2000) discusses problems of lining and excavation in case of large caverns on the tunnel path. Due to frequent floods of the Kuhrang III tunnel in Iran (23 km long), excavation time (proposed by design) was more than doubled. At one of the number of similar cases, in this tunnel the huge water inflow from the tunnel face under pressure of 26 bars 


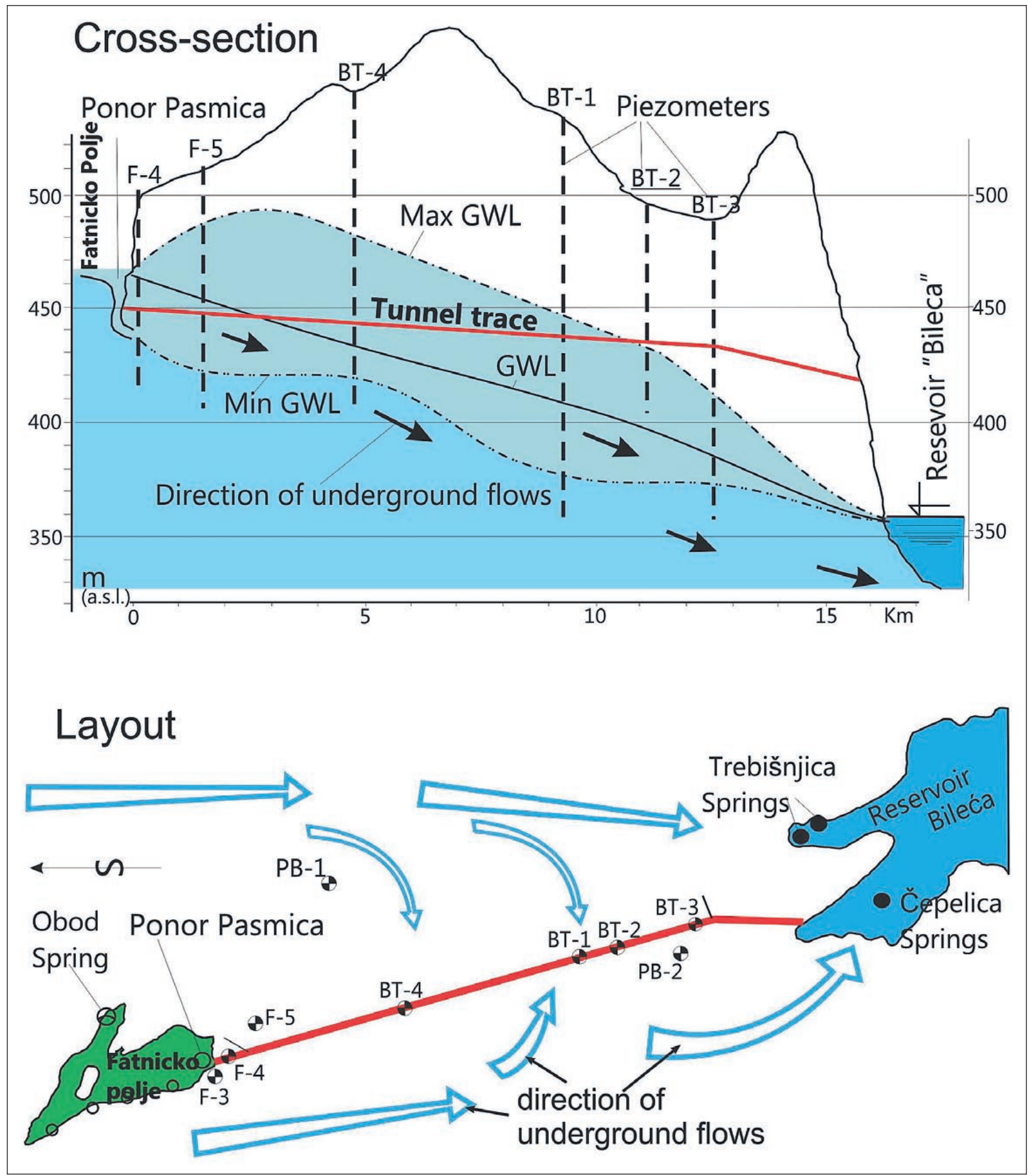

Fig. 16: Tunnel Fatničko Polje - Reservoir Bileća, Herzegovina, for different stages of groundwater level and direction of underground flows (after Milanović 2006).

increased up to a peak of $1.2 \mathrm{~m}^{3} / \mathrm{s}$ in only four hours. For 24 hours, more than $1000 \mathrm{~m}^{3}$ of sediments such as boulders, gravel, sand and silty material was washed out from the cavernous system ahead and around the tunnel boring machine (TBM) head.
The application of a tunnel boring machine (TBM) in karst is a particularly delicate task. Every cavern or fault zone in front of the head of the TBM means an excavation delay of a few days up to a few months. If the cavity is filled with plastic clay, boring efficiency 


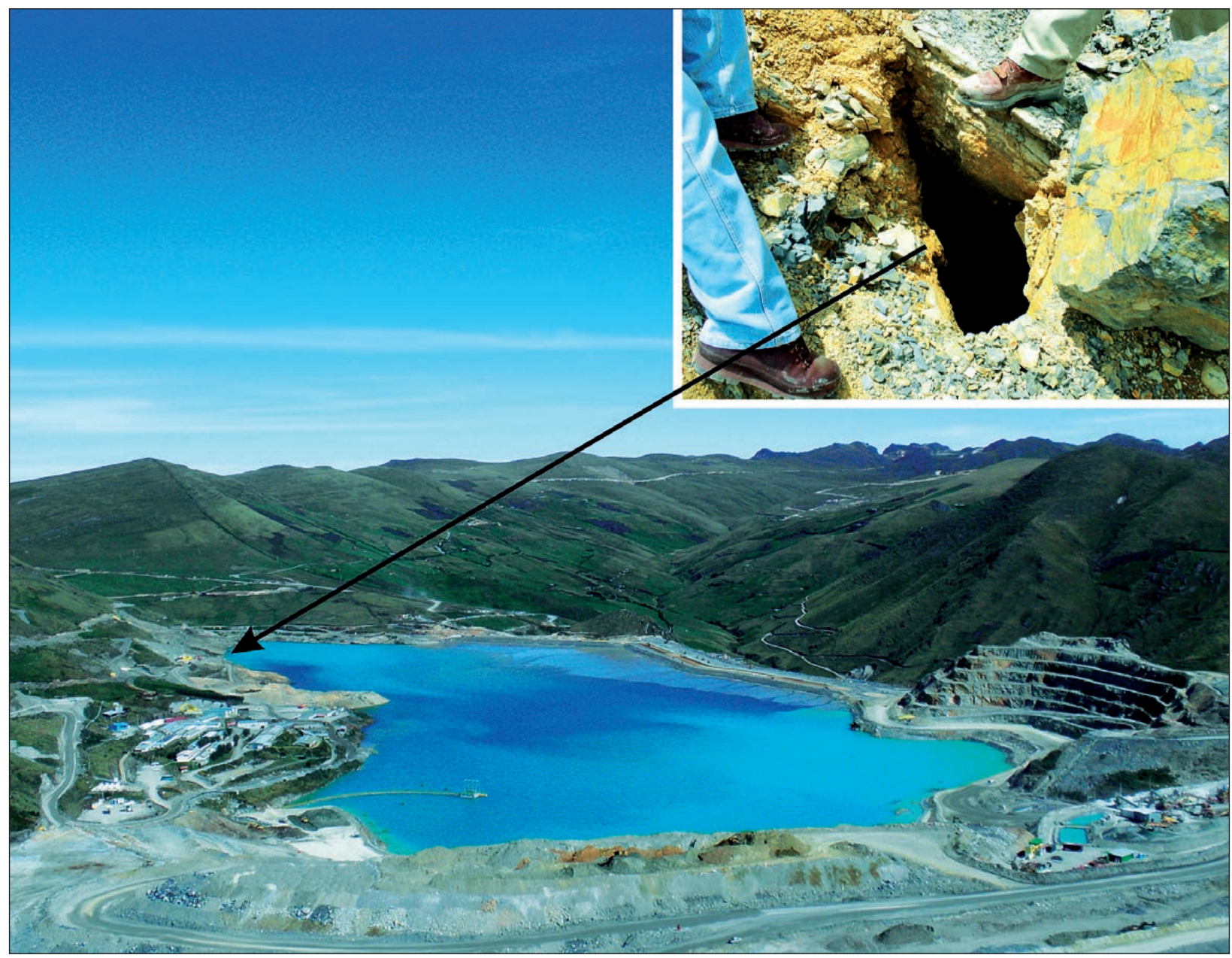

Fig. 17: Cerro Corona tailings, Peru. Photo in corner: karstified Cretaceous limestone (Photos: P. Milanović).

is additionally low. The problem of excessive free space should be overcome by cavern filling, bridging or bypassing. However, TBM is not a flexible machine and is vulnerable in the case of a flood (Milanović 2000). Cavities thus cause high pressures and sudden inrushes. In such conditions tunnel drainage (channels, pumps) is necessary part of the final design, aggravating engineers' attention (Milanović 2000).

\section{MINING IN AND AROUND KARST}

Many mines in the world are situated in karstified rock. In China more than 50 coal mines in karst have serious problems due to massive groundwater inflow, between 1 and $40 \mathrm{~m}^{3} / \mathrm{s}$ (Yuan 1991). However, the problem related to karst water does not occur in the case of coal mines only: a number of zinc, lead, gold and iron ore mines are within karstified carbonate rocks. They might result from the process of hydrothermal karstification when ore deposits represent paleokarst structures. In many ore mines large open caverns were discovered: Pine Point, $\mathrm{Zn} /$ $\mathrm{Pb}$ mine (Canada); Yatela gold mine (Mali); Olkuzs and
Pomorzany, $\mathrm{Zn} / \mathrm{Pb}$ mine (Poland) and many others. As a consequence of karstification, all the mines mentioned face very complex, mostly hydrogeological problems.

The direct excavation of minerals from karstified rocks (e.g. bauxites) or work in their proximity threats the mining operations. And in the case of underground mining in saturated zones, the number of threats is on the rise. Intersecting major karst conduits due to a lack of knowledge about the hydrogeological conditions often leads to inrushes of groundwater into mining works. A mine can be flooded over a very short time, causing human casualties and considerable loss (Dragišić 2015).

One of the examples of very large and constant inflow into the bauxite deposits is in Hungary northwest of Balaton Lake, in the Halimba and Nyrad districts. The bauxites overlie confined thick Triassic and Jurassic limestones and dolomites. The total amounts of water pumped from the karst aquifer in the early 1980s was about $5 \mathrm{~m}^{3} / \mathrm{s}$.

The previously discussed problem of subsidence is often a result of uncontrolled groundwater pumping 
and groundwater table depletion in unconsolidated cover of karst depression. However, the underground mining in karst and extraction of a large volume of the rocks may also causes collapses. Such a combination of negative natural precondition and anthropogenic impact was registered in the Perm region of Russia. The inflow rates into the Bereznikovsky potassium salt mine began to increase in January 1986: from about $15 \mathrm{l} / \mathrm{s}$, after two months it had reached more than $500 \mathrm{l} / \mathrm{s}$. The mine was completely flooded while a large cavity had been created above the mine. Finally, the ground surface collapsed at the end of July of that year with an ellipsoidal sink $40 \times$ $80 \mathrm{~m}, 170 \mathrm{~m}$ deep (Dragišić 2015).

Leakage from tailings is a major threat for karst and the quality of its groundwater. This especially applies to non-ferrous ore deposits such as those of $\mathrm{Cu}, \mathrm{Pb}, \mathrm{Zn}, \mathrm{Sb}$, and Hg. The Cerro Corona tailings in Peru are situated partially within karstified carbonate formations at an elevation of about $3800 \mathrm{~m}$ (Fig. 17). To achieve the successful seepage prevention and protection of local springs, very detailed and complex geological and hydrogeological investigations and analyses were applied and massive geotechnical measures were done: construction of huge compaction blankets; application of different geomembranes; construction of multirow grout curtains; and construction of complex drainage systems.

However, not all groundwater from or in contact with ore deposits is problematic, and some, such as that from bauxites, can even be used for local drinking water supply.

\section{ENVIRONMENTAL IMPACT OF ENGINEERING WORKS}

In contrast to the first half of the $20^{\text {th }}$ century when characteristically "A man changed nature according to his needs", today it is more apt to say "A man adapts his technical solutions to the environmental requirements". This great change results from the concept of Sustainable development introduced widely into social and political life in the 1990s (Stevanović 2011).

The Environmental Impact Assessment Study (EIAS) was introduced into engineering practice in the 1970s and today almost every technical solution should conform to environmental conditions. With the exception of some small projects, assessing the impact of serious interventions has become in most countries an obligatory part of technical documentation.

Environmental impact indicators are the tools for making visible and assessing the magnitude of the implemented project on the vulnerable elements of nature. There are many references and projects related to environmental indicators which cover different components of aquatic systems: Vrba and Lipponen (2007) define groups of indicators helping to evaluate pressures on water quantity and on water quality; Preda et al. (2012) classify the indicator packages into three groups (hydrogeomorphological, physico-chemical, biological); the project DIKTAS resulted in an initial list comprising 23 different parameters for assessing pressures on groundwater quantity and quality and resulting pressures on dependent ecosystems in selected aquifers of transboundary concern (Stevanović 2014).

There are many steps to be introduced to keep the balance between the necessity for socio-economic de- velopment and the preservation of sensitive and unpredictable karst environments (Milanović 2002). There are also some other methods or concepts to assess the impact on karst environment. As such, the Karst Disturbance Index (KDI), as a way to determine the impact deriving from human activities, has been tested and applied in several regions (North et al. 2009). KDI consists of 31 environmental indicators contained within five categories: (1) geomorphology, (2) hydrology, (3) atmosphere, (4) biota, and (5) cultural. Such an environmental index approach to assess karst terrains enables scientists to measure, compare, and contrast the condition of karst environments spatially and temporally and to guide the future mitigation action aimed at minimizing the disturbance to the natural environment (Parise 2015).

The vulnerability mapping (Ravbar 2007) should be an integral and important part of the planning process for every kind of engineering works in karst.

Knez and Slabe (2009) demonstrate the importance of monitoring during construction works and of close cooperation between engineers and environmentalists. They state that as an important part of Slovenian natural heritage more than 350 caves opened during the construction of motorways over the classical Kras region. The karstologists are deeply involved in the planning and selection of routes which are chosen to avoid important karst features (poljes, dolines, caves). Special attention is devoted to karst waters, and the practice is intended to make all motorways impervious and to evacuate runoff water to collectors. 


\section{CONCLUSIONS}

To adapt karst and its nature sustainably is not an easy task. The history of engineering works in karst is very long and consists of very successful implemented projects and solutions but also many registered failures.

The majority of engineering works in karst are related to water. The three major groups of problems and resulting interventions are related to: Water resources using - effective utilization of karstic water resources for water supply, irrigation, heating and other purposes; Dewatering - mitigation of karst inflow in mining, urban areas, around or below dams or other construction works, reduction of floods; and Protecting - prevention of pollution and remediation of karst water quality. All three groups consist of a number of different tasks and challenges.

But there are also plenty of problems occurring in dry karst terrain or in its unsaturated zone and many measures should be applied to prevent or mitigate natural and anthropogenic hazards.

Considerable damage in construction works in the karst environment may happen however extensive the investigations undertaken are, but proper interpretation of collected information and appropriate design can minimize and reduce them to an acceptable level.

The important issue in karst regions for the future is how to keep a balance between the necessity for socio-economic development and the preservation of a sensitive, complex and unpredictable karst environment. Therefore, along with economical feasibility and assessment of logic of engineering works, the impacts to environment must precceed any practical intervention.

\section{REFERENCES}

Atkinson, T.C., 1986: Soluble rock terrains.- In: Fookes P, Vaughan PR (eds.) Handbook of engineering geomorphology. Chapman and Hall, New York, pp. 241-257

Avias, J., 1984: Captage des sources karstiques avec pompage en periode d'etiage. L'example de la source du Lez.- In: Burger A and Dubertret L (eds) Hydrogeology of karstic terrains. Case histoires. International Contributions to Hydrogeology, IAH, vol. 1. Verlag Heinz Heise, Hannover, pp 117-119

Bakalowicz, M., Fleury, P., Dörfliger, N., Seidel, J.L., 2003: Coastal karst aquifers in Mediterranean regions. A valuable ground water resource in complex aquifers.IGME Publ., Technologia de la Intrusion de Agua de Mar en Acuiferos Costeros: Paises Mediterraneos (TIAC). Hydrogeologia y aguas subterraneas no. 8, Alicante, 2: 125-140

Bakalowicz, M., 2005: Karst groundwater: a challenge for new resources.- Hydrogeol J, 13: 148-160

Bonacci, O., 1987: Karst hydrology with special reference to the Dinaric karst.- Springer-Verlag, Berlin

Bono, P., Boni, C., 1996: Water supply of Rome in antiquity and today.- Environ. geol. 27/2: 126-134

Brown, L., 2013: The real threat to our future is peak water.- The Observer, Saturday 6 July 2013
Burke, J.J., Moench, H.M., 2000: Groundwater and society: Resources, tensions and opportunities.-Spec ed. of DESA and ISET, UN public. ST/ESA/265, New York. pp. 170

De Waele, J., Gutierrez, F., Parise, M., Plan, L., 2011: Geomorphology and natural hazards in karst areas: a review.- Geomorph 134(1-2): 1-8

Dragišić, V., 2015: Karst aquifers and mining: conflicts and solutions. - In: Karst Aquifers - Characterization and Engineering (Stevanović Z. ed), Series: Professional Practice in Earth Science, Springer International Publishing Switzerland, pp. 550-567

Fleury, P., 2005: Sources sous-marines et aquifères karstiques côtiers méditerranéens. Fonctionnement et caractérisation.- Thèse géol. de $3^{\circ}$ cycle, Université Paris VI, pp. 286

Ford, D., Williams, P., 2007: Karst hydrogeology and geomorphology.- Wiley, Chichester, pp. 562

Ford, D., 2014: Expect the unexpected! Groundwater flow in karstified carbonate aquifers.- In: Mudry J, Zwahlen F, Bertrand C, LaMoreaux JW (Eds.) H2Karst Research in Limestone Hydrogeology, Environmental Earth Sciences, Springer, pp. 1-17

Frumkin, A., Shimron, A., 2006: Tunnel engineering in the Iron Age: geoarchaeology of the Siloam Tunnel, Jerusalem.- Journal of Archaeological Science, 33: 227-237 
Goldscheider, N., Drew, D., (eds) (2007): Methods in karst hydrogeology.- International Contribution to Hydrogeology, IAH, vol 26, Taylor \& Francis/Balkema, London, pp.264

Goldscheider, N., 2015: Overview of methods applied in karst hydrogeology.- In: Karst Aquifers - Characterization and Engineering (Stevanović Z. ed), Series: Professional Practice in Earth Science, Springer International Publishing Switzerland, pp. 126-145

Kang, Y.R., Zhang, B.R., 2002: Karst and engineering handling to the karst in Wulichong reservoir, Yunan Province.- Carsologica Sinica, vol 21(2)

Knez, M., Slabe, T., 2009: Uncovered caves and their conservation during the construction of motorways over classical karst and other types of Slovenian karst.- In: Andreo B., Carrasco F., Duran J.J., LaMoreaux J.W. (eds.) Advances in Research in Karst Media, Springer, Heidelberg, pp. 401-406

Krešić, N., 2013: Water in karst. Management, vulnerability and restoration.- McGraw Hill, New York, pp. 708

Krešić, N., Mikszewski, A., 2013: Hydrogeological conceptual site model: Data analysis and visualization.CRC Press, Boca Raton, FL, pp. 584

Lombardi, L., Corazza, A., 2008: Lacqua e la città in epoca antica.- In: La Geologia di Roma, dal centro storico alla periferia, Part I, Memoire Serv. Geol. d'Italia, Vol LXXX, S.E.L.C.A, Firenze, pp. 189-219

Margat, J., Gun van der, J., 2013: Groundwater around the World: A Geographic Synopsis.- CRC Press, Taylor \& Francis Group, Boca Raton, pp. 348

Marinos, P., 2005: Experiences in tunnelling through karstic rocks.- In: Stevanović $\mathrm{Z}$ and Milanović $\mathrm{P}$ (eds) Water resources and environmental problems in karst, Proceedings of international conference KARST 2005, University of Belgrade, Institute of Hydrogeology, Belgrade, pp. 617-644

Milanović, P., 1981: Karst hydrogeology.- Water Resources Publications, Littleton, CO, pp. 434

Milanović, P. 2000: Geological engineering in karst. Dams, reservoirs, grouting, groundwater protection, water tapping, tunneling. Zebra Publ. Ltd, Belgrade pp. 347

Milanović, P., 2002: The environmental impacts of human activities and engineering construction in karst. Episodes, Journal of International Geoscience, Vol.25 No.1

Milanović, P. 2004: Water resources engineering in karst.CRC Press, Boca Raton, FL, pp.328

Milanović, P., 2006: Karst of eastern Herzegovina and Dubrovnik littoral.- ASOS, Belgrade, pp. 362
Milanović, P., 2014: Hydraulic properties of karst groundwater and its impacts on large structures.- In: Mudry J, Zwahlen F, Bertrand C, LaMoreaux JW (Eds.) H2Karst Research in Limestone Hydrogeology, Environmental Earth Sciences, Springer, pp. 19-48

Milanović, P., 2014b: Optimal water management - prerequisite for regional socio-economic development in karst.- In: Kukurić N, Stevanović Z, Krešic N (eds) Proceedings of the DIKTAS Conference: "Karst without boundaries", Trebinje, June 11-15 2014, pp. $15-22$

Milanović, P., 2015: Catalog of engineering works in karst and their effects.- In: Karst Aquifers - Characterization and Engineering (Stevanović Z. ed), Series: Professional Practice in Earth Science, Springer International Publishing Switzerland, pp. 360-398

Milanović, S. and Vasić, LJ., 2014: 3D modeling of karst conduit; case example leakage below Višegrad dam.In: Kukurić N, Stevanović Z, Krešic N (eds) Proceedings of the DIKTAS Conference: "Karst without boundaries", Trebinje, June 11-15 2014, pp. 301-306

North, L.A., van Beynen, P.E., Parise, M. 2009: Interregional comparison of karst disturbance: West-Central Florida and Southeast Italy.- J Environ Manag 90:1770-1781

Paloc, H., Mijatović, B., 1984 : Captage et utilisation de l'eau des aquiferes karstiques.- In: Burger A and Dubertret L (eds) Hydrogeology of karstic terrains. Case histoires. International Contributions to $\mathrm{Hy}$ drogeology, IAH, vol. 1. Verlag Heinz Heise, Hannover, pp. 101-112

Parise, M., Gunn, J., (eds) 2007: Natural and anthropogenic hazards in karst areas: Recognition, Analysis and Mitigation.- Geol. Soc., London, sp publ 279, pp. 59-72

Parise, M., 2015: Hazards in karst environment and mitigation measures.- In: Karst Aquifers - Characterization and Engineering (Stevanović Z. ed), Series: Professional Practice in Earth Science, Springer International Publishing Switzerland, pp. 601-613

Preda, E., Kløve, B., Kværner, J. et al., 2012: New indicators for assessing groundwater dependent eco systems vulnerability.- Delivereable 4.3. GENESIS FP 7 project: Groundwater and dependent eco systems, pp. 84

Ravbar, N., 2007: The protection of karst waters - a comprehensive Slovene Approach to vulnerability and contamination risk mapping.- ZRC Publishing, Karst Research Institute at ZRC SAZU 6: Carsologica, Postojna, Ljubljana 
Reade, J., 1978: Studies in Assyrian geography, Part 1: Sennacherib and the waters of Ninveh.- Revue D'Assyriologie Orientale 72: 47-72, 157-175

Smart, P.L., Hobbs, S L., 1986: Characterisation of carbonate aquifers: A conceptual base. Environmental problems in karst terranes and their solutions: Bowling Green, National Water Well Association, pp. $1-14$

Stevanović, Z., Iurkiewicz, A., 2009: Groundwater management in northern Iraq.- Hydrogeol J, 17 (2): 367-378

Stevanović, Z., 2010: Utilization and regulation of springs.In: Kresic N and Stevanovic Z (eds) Groundwater hydrology of springs. Engineering, theory, management and sustainability. Elsevier Inc. BH, Amsterdam, pp. 339-388

Stevanović Z., Eftimi R., 2010: Karstic sources of water supply for large consumers in southeastern Europesustainability, disputes and advantages.- Geologica Croatica, 63/2: 179-186

Stevanović, Z., 2011: Management of groundwater resources; in Serbian.- University of Belgrade - Faculty of Mining \& Geology, Belgrade, pp. 340

Stevanović, Z., 2014: Environmental impact indicators in systematic monitoring of karst aquifer - Dinaric karst case example, In: Kukurić N, Stevanović Z, Krešic N (eds) Proceedings of the DIKTAS Conference: "Karst without boundaries", Trebinje, June 11-15 2014, pp. 80-85

Stevanović, Z., 2015a: Characterization of karst aquifer.In: Karst Aquifers - Characterization and Engineering (Stevanović Z. ed), Series: Professional Practice in Earth Science, Springer International Publishing Switzerland, pp. 47-125

Stevanović, Z., 2015b: Managing karst aquifers - Conceptualizion, solutions, impacts.- In: Karst Aquifers - Characterization and Engineering (Stevanović Z. ed), Series: Professional Practice in Earth Science, Springer International Publishing Switzerland, pp. 403-419
Stevanović, Z., 2015c: Engineering regulation of karstic springflow to improve water sources in critical dry periods.- In: Karst Aquifers - Characterization and Engineering (Stevanović Z. ed), Series: Professional Practice in Earth Science, Springer International Publishing Switzerland, pp. 490-530

Tolmachev, V., 2005: Issues of environmental impacts of karst in standards on construction in Russia.- In: Stevanović Z and Milanović P (eds) Water resources and environmental problems in karst, Proceedings of international conference KARST 2005, University of Belgrade, Institute of Hydrogeology, Belgrade, pp. 713-718

Tolmachev, V., 2013: Karst risk assessment for engineering in Nizhny Novgorod Region, Russia.- Proceedings of the International Conference "Natural Hazards Links between Science and Practice", Belgrade, pp. 11-22

Vrba. J., Lipponen, A., 2007: Groundwater resources sustainability indicators.- IHP -VI Series on Groundwater No.14, UNESCO, Paris

White, W.B., 1977: Conceptual models of carbonate aquifers.- Revisited In: Hydrologic problems in karst regions (Dilamarter R.R. and Csallany S.C. eds.). Bowling Green, Kentucky, Western Kentucky University, pp. 176-187

Yuan, D., 1990: Construction of underground dams on subterranean streams in South China Karst.- Institute of Karst Geology, Guilin

Yuan, D., 1991: Karst of China.- Geological Publishing House, Beijing 